\title{
The Impact of Purbalingga Regency Superior Product Aid on Batik, Bamboo, and Sculpture Crafts after the Covid-19 Pandemic
}

\author{
Kurniawan, Dede Nurdiawati, Noviea Varahdilah Sandi, Sugeng Riyanto \\ Universitas Peradaban \\ E-mail: kurniawan@peradaban.ac.id
}

\author{
Article History: \\ Received: \\ Revised: \\ Accepted: \\ Keywords: collaboration of \\ craftsmen, batik, bamboo, \\ sculpture crafts.
}

\begin{abstract}
The COVID 19 pandemic has had a big effect on Indonesia's small and medium-sized enterprises (SMEs), including changes in people's buying power, turnover, SME output, and numerous other unprofitable changes, especially in Purbalingga SMEs. This community service is aimed at increasing the competitiveness of the superior products of Purbalingga Regency through increasing the value of products in Small and Medium Enterprises (UKM) of Batik, Bamboo, and Sculpture Crafts. The program was carried out by counseling and mentoring methods, by utilizing technology efficiency, training in the use of tools, and optimization of partnerships. The results achieved include the successful implementation of new strategies to survive in new normal conditions, starting from changing the function of the product, carrying out the collaboration between batik, bamboo and wood craftsmen, and more intensive online marketing, collaborating, implementing creativity and innovation that increase product value, so that the turnover and quality of superior products increases and has high competitiveness.
\end{abstract}

\section{Introduction}

The COVID 19 pandemic has given a great impact on Small and Medium Enterprises (SMEs) in Indonesia, including the changes towards decreasing people to purchasing capacity, turnover, SMEs performance and various other changes that show unprofitable ${ }^{1}$. They are trying to survive in despite of the financial conditions leads to an unsafe point. They do not consider how much income is earned, but rather to the operations that can be continued. Business owners are trying to restore this condition, but many of them encounter the problem even it is getting worse. Some owners who succeed in formulating strategies they must be able to save employees, formulate innovative product, strive to utilize their resources and take the right opportunities for

1 Aknolt Kristian Pakpahan, “Covid-19 Dan Implikasi Bagi Usaha Mikro, Kecil, Dan Menengah,” Jurnal Ilmiah Hubungan Internasional (2020): 59-64. 
their business ${ }^{2}$.

Reversion of the condition requires intensive cooperation from various parties, both suppliers, suppliers between SMEs ${ }^{3}$, or collaboration with universities in this case with the University of Peradaban and the Regional Government of Purbalingga Regency in an effort to make serious efforts to return the new normal condition, focus on increasing productivity and efficiency in cost expenditures, so that the value of the product can increase and the product can be received by the community. There are at least three SMEs which concern to be improved in Program Pengembangan Produk Unggulan (PPPUD) in Purbalingga Regency, namely Batik, bamboo and wood crafts or sculpture. The large number of craftsmen often do not all get assistance by the Purbalingga Regency Cooperative and UMKM Office ${ }^{4}$, meanwhile assistance by the service is very helpful and needed by $\mathrm{UKM}^{5}$, but this assistance is very limited so it takes the role of universities in establishing cooperation to improve the performance of SMEs in each region.

Purbalingga Batik centres are scattered in several villages in-between Mindik Gandasuli Bobotsari District. It is followed by several other districts such as Karanganyar, Bojongsari, Purbalingga, Karangmoncol, and Kemangkon District. The numbers of Batik groups in Purbalingga are 12 active Batik groups. One of the active groups is the Sekarsari group in the village of Gambarsari Village, Rt. 04 / Rw. 2 Kemangkon Purbalingga Regency. Batik craftsmen must have a competitive advantage for their products ${ }^{6}$, such as group of Batik Sekarsari produces Purbalingga Batik which is classified as interior Batik, which tends to have larger, expressive motifs with small-sized plant and animal motifs. It has a distinctive style of filling and decorative ornaments. The Sekarsari group combines

\footnotetext{
${ }^{2}$ Alvin Arifin, "Manajemen Sumber Daya Manusia Pada Masyarakat Desa," Bunga Rampai Gubahan Akademisi Manajemen 2019 (2019): 1.

${ }^{3}$ Lila Bismala, "Analisis Strategi Pemasaran Pada UMKM Di Sumatera Utara Untuk Meningkatkan Daya Saing UMKM," Jurnal Pembangunan Perkotaan 2, no. 2 (2014): 126-134.

${ }^{4}$ Kurniawan Kurniawan et al., "Peningkatan Skill Teknologi Pengrajin Produk Unggulan Kabupaten Purbalingga Pada Kerajinan Batik, Kerajinan Bambu Dan Seni Patung," Jurnal Abdimas PHB: Jurnal Pengabdian Masyarakat Progresif Humanis Brainstorming 3, no. 1 (2020): 32-46; Abdur Rozaki and Siti Rohaya, "Memberdayakan Desa Melalui Pariwisata Berbasis BUMDES," Engagement: Jurnal Pengabdian $\begin{array}{llllll}\text { Kepada } & \text { Masyarakat } & 3, & \text { no. } & 1 & \text { (2019): }\end{array}$ http://engagement.fkdp.or.id/index.php/engagement/article/view/46.

${ }^{5}$ Muhammad Ridwan and Massad Hatuwe, "Pembinaan Industri Kecil Dan Menengah Pada Dinas Perindustrian, Perdagangan, Koperasi Dan UMKM Kota Bontang," Jurnal Administrative Reform (JAR) 2, no. 2 (2017): 187-199; Luluk Tri Harinie and Alexandra Hukom, "Pendampingan Dalam Memasarkan Produk Hasil Usaha UKM Melalui Penggunaan Media Sosial Di Kabupaten Gunung Mas Kalimantan Tengah," Engagement: Jurnal Pengabdian Kepada Masyarakat 4, no. 1 (2020): 51-59, http://engagement.fkdp.or.id/index.php/engagement/article/view/179.

${ }^{6}$ Muhamad Ikqbal, "Pengaruh Desain Produk Dan Kualitas Produk Terhadap Keunggulan Bersaing (Survey Pada Pengrajin Batik Di Kota Tasikmalaya)” (Universitas Siliwangi, 2020); Rangga Sa'adillah Sandhy Atma Putra, "Pembelajaran Pendidikan Agama Islam Melalui Pendekatan Saintifik Dalam Membentuk Sikap Spiritual Siswa Sekolah Menengah Atas Di Sidoarjo (Studi Fenomenologi Pengalaman Guru Dan Siswa Pada SMA Di Sidoarjo)" (Universitas Muhammadiyah Malang, 2020), http://eprints.umm.ac.id/65683/.
} 
interior Batik with contemporary motifs ${ }^{7}$, this is being the main characteristic of Sekarsari's compared to other regions that mostly make classic motifs. However, it takes creativity to compete with the industry in terms of quantity, so that their business can continue to run.

The Sekarsari Batik Group has successfully developed its batik skills by using the tamarin or better known as cold waxing method, as a very new process, which is mixed with tamarin seed powder. The process is quite easy by mixing the powdered tamarin seeds with a little butter and hot water. After becoming a dough that is somewhat smooth and not too thick, the cold waxing ingredient is ready to use $\mathrm{e}^{8}$, The results of assistance to the Sekarsari group include speeding up the production process of 150 pieces in one hour to meet the needs of the cloth market share, especially in Purbalingga Regency.

Istana Bambu is the next crafting group. The Bamboo Palace is chaired by Hentri Guntoro who is believed to be the head of a group that has 30 members which spread across several villages in Kemangkon District, Hentri Guntoro is very active in several local government activities, to increase the stretching of craftsmen, it takes a drive from them ${ }^{9}$, this is as a direct actor who produces various types of handicrafts from bamboo, established in 2004 until now. Istana Bambu has consistently developed bamboo handicrafts, which have never experienced a lack of buyers, standing in the village of Bakulan Village, Rt. 11 / Rw. 05 Kemangkon Purbalingga Regency. Istana Bambu has superior products such as serving covers, trays, bamboo Batik dining mats, sada plates, gazebos, bridal backgrounds, tissue holders, patio chairs, miniature gazebos, and many other products produced by this business group, to achieve success, they must be consistent with their products in carrying out development and quality improvement ${ }^{10}$.

A good marketing network through partnerships is essential ${ }^{11}$, in addition to Istana Bambu which has long been consistently against bamboo craft, also formed a partnership and develop the local area artisans like Village Bokol and Kedungbenda that have made Gallery Istana Bambu to accommodate the beginners which is assisted by Istana Bambu and the Department of Cooperatives and SMEs in Purbalingga district. Meanwhile, market orders from the cities of Tasik and Ciamis continue to flow, so that

${ }^{7}$ Siti Zulaikha Wulandari, Suwaryo Suwaryo, and Suci Indriati, "Peningkatan Kapasitas Usaha Batik Cap Motif Khas Pesona Gua Lawa Bagi Kelompok Batik Sekarsari Purbalingga," in Prosiding, vol. 7, 2017; Ariesa Pandanwangi et al., "Pendampingan Komunitas Pembatik Melalui Pelatihan Alih Pengetahuan Membatik Dengan Material Berbasis Kearifan Lokal," Engagement : Jurnal Pengabdian Kepada Masyarakat 3, no. 1 (2019): 68-79, http://engagement.fkdp.or.id/index.php/engagement/article/view/51.

8 Kurniawan et al., "Peningkatan Skill Teknologi Pengrajin Produk Unggulan Kabupaten Purbalingga Pada Kerajinan Batik, Kerajinan Bambu Dan Seni Patung."

9 Rahayu Permana, "Topi Bambu Tangerang (Kearifan Lokal Berbasis Ekonomi Kreatif)," Tsaqofah 17, no. 2 (2019): 137-148.

10 Tuwaidan Anis, "PKM Kelompok Pengrajin Sofa Di Desa Watutumou Kecamatan Kalawat Kabupaten Minahasa Utara Provinsi Sulawesi Utara," Lex Et Societatis 6, no. 8 (2019): 31-37.

11 Nadia Sigi Prameswari, Pratama Bayu Widagdo, and Eko Sugiarto, "Perluasan Jaringan Pemasaran Melalui Kemitraan Dengan Marketplace Bagi PKL Dampak Relokasi Pemkot Surakarta," Citradirga-Jurnal Desain Komunikasi Visual dan Intermedia 1, no. 2 (2019): 1-8. 
the production process has never experienced a lack of buyers, increasing the extent of the marketing area, so that Istana Bambu can last until now.

The next partner is the Akar Wijaya Business group, Akar Wijaya, which is engaged in the handicraft making of sculpture. Chaired by Nyarjan Printo, who has been in the field since 2015, having his address at Kedungbenda Village, Rt. 03 / Rw. 04 Kemangkon District, Purbalingga Regency. Initially, this group were ordinary woodworkers or often referred to as carpenters ${ }^{12}$. Often times, the wood business faces more and more competition, so, Prianto is no exception, starting to pioneer in developing sculpture making.

Wood craftsmen are expected to be able to compete in the global market ${ }^{13}$, apart from having clear institutions, cooperation between them is needed, as well as supporting each other, mutual support in providing different skills, Akar Wijaya institutional members such as Wahyu, Arwoto, Kusmo, Dayat, Minu and Sunar, initially they are craftsmen who worked individually, the results of the assistance had brought them together to collaborate both in marketing and production, arranging a division of management tasks, the resulting products varied from deer statues, horse statues, animated film sculptures, statues of wolves, statues of forest people, statues of peacocks, statues of the rooster, bonsai, ashtrays, and various other types of crafts made from bamboo and wooden roots but the size is reduced.

The selection of partners for the superior product mentoring cooperation is based on the 2017 Purbalingga District RPJMD to improve the competitiveness of batik, bamboo and wood craftsmen, which are iconic of Purbalingga in their increasingly quality products, this assistance is a form of mutual support in improving performance and returning to conditions. all postCovid-19, After the pandemic entered Purbalingga, their business experienced a setback, one month's sales experienced zero, buyers were very quiet and products did not sell in the market, The results of implementing PPPUD program activities in Purbalingga Regency included partner turnover began to increase by $30 \%$, and the community was involved in various supporting efforts, increased access to financial institutions, improved bookkeeping administration through E-Accounting EMKM, increased production cost efficiency, increased product value, product innovation, added new members, and availability of online marketing.

This is an effort to overcome various problems faced, such as low access to finance and savings, no calculation of how many assets are owned and used as credit guarantees, production costs are still inefficient, labor resources are increasingly limited and product

12 Devi Rizki Amalia, Sri Nuringwahyu, and Ratna Nikin Hardati, "Analisis Lingkungan Dalam Menentukan Strategi Yang Tepat (Studi Pada Kerajinan Kayu Tohu Srijaya Kota Batu)," Jiagabi (Jurnal Ilmu Administrasi Niaga / Bisnis) 7, no. 3 (2018): 109-116.

13 Komang Ary Niatika Arka Sudarsana, "Analisis Skala Ekonomis Industri Kerajinan Patung Kayu Di Kecamatan Ubud Kabupaten Gianyar," E-Jurnal Ekonomi Pembangunan Universitas Udayana 9, no. 10 (October 18, 2019): 195-2500, https://ojs.unud.ac.id/index.php/eep/article/view/46197. 
variations are not in accordance with market needs.

\section{Method}

The approach and selection of science and technology in this program are as follows:

First, Counselling regarding the preparation of bank loan proposals to partners, steps that are taken are coordination with financial institutions in Purbalingga Regency and preparation of simple recording requirements, Partner Participation prepares credit guarantees owned by partners. Evaluation Steps Analysis of the amount of credit received growth trends up to 2020, a list of inventory of financial assets held.

Second, Preparation of financial reports using E-Accounting EMKM, procurement of smartphone devices, preparation of manual transaction lists, calculation of assets, debt and capital used. Partner Participation includes preparing a transaction register book, calculating a list of assets owned and determining the accounting policies to be used. Evaluation Steps include the number of partners who use EMKM E-Accounting in preparing financial reports and print out financial reports for partner members who have successfully carried out simple bookkeeping.

Third, Training and counselling on increasing the efficiency of production costs, preparation of standard module material for production work, standard material handling module books, minimum standard module books for raw materials and book modules on the use of appropriate technology. Participation Partners use module books as standard for work implementation. Steps to evaluate are the number of SOPs generated, total expenses, total profit per monthly period.

Fourth, Counselling to prospective new members at Sekarsari partners, Istana Bambu and Akar Wijaya, steps taken are to collect data on potential new members, identify needs for production lines, marketing lines and financial management lines. Participation Partners invite people around the location of the business place who have the desire and potential for entrepreneurship. The Evacuation Step calculates the number of new members and the quantity generated from these new members.

Fifth, Counselling and training to partners on product innovation, procurement of motive training materials, procurement of woodcraft design training materials. Partner Participation includes documenting a list of batik motifs, documenting a list of bamboo handicraft products, documenting the list of wood crafts produced, documenting a list of ornaments of each product and each partner. The Evaluation Step calculates the number of new products produced by partners. Using extension and training methods, the PPPUD process flow can be explained in Figure 1. 


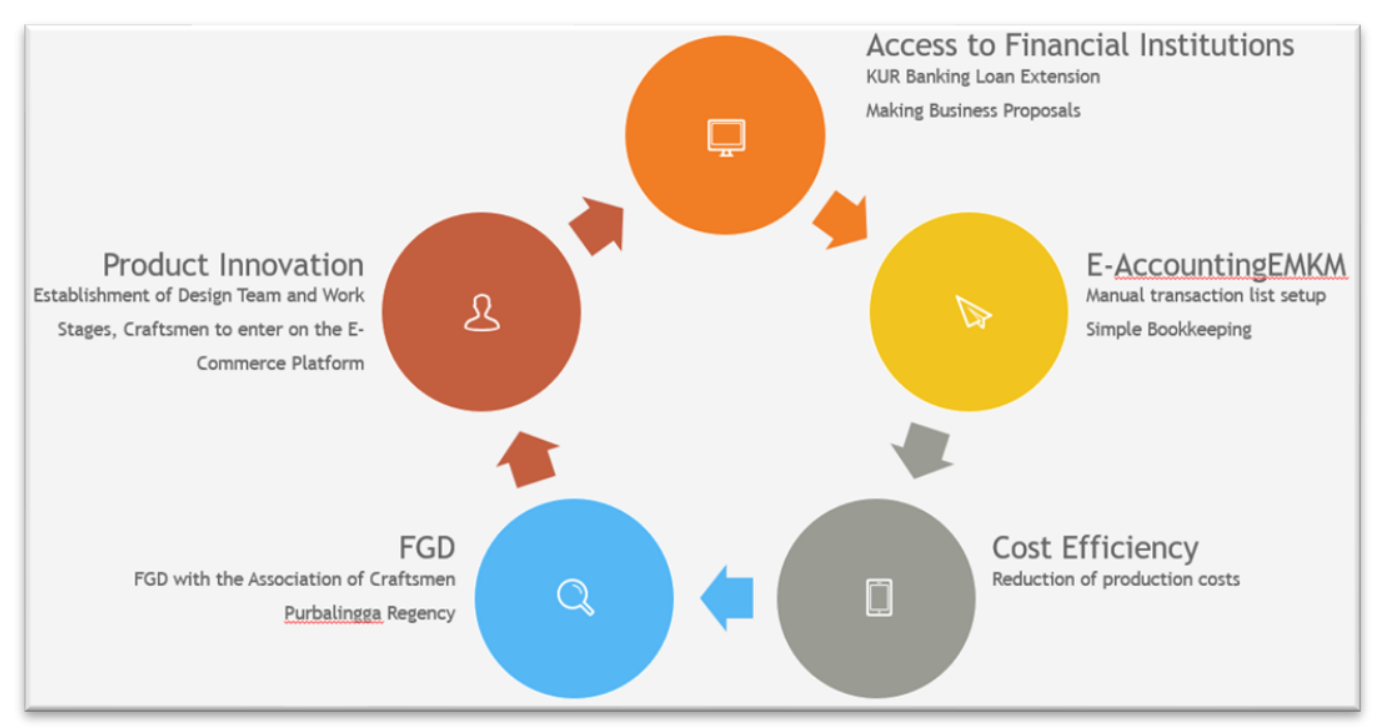

Figure 1. The Flow of PPPUD Implementation Process

\section{Results}

The results of the benefits obtained based on the activities of the Program Pengembangan Produk Unggulan (PPPUD) in Purbalingga Regency can be explained as follows: The benefits obtained based on the activities of the Purbalingga Regency Superior Product Development Program can be explained as follows: Increase partner turnover by $30 \%$ after the Covid-19 pandemic, the Covid-19 pandemic reduced partner turnover for several months, even at zero percent, but massive marketing increased turnover on online purchases. Based on the diffusion of innovation theory ${ }^{14}$ that the increasing number of SMEs are marketing online, it encourages an increase in individuals to adopt online marketing so that turnover increases.

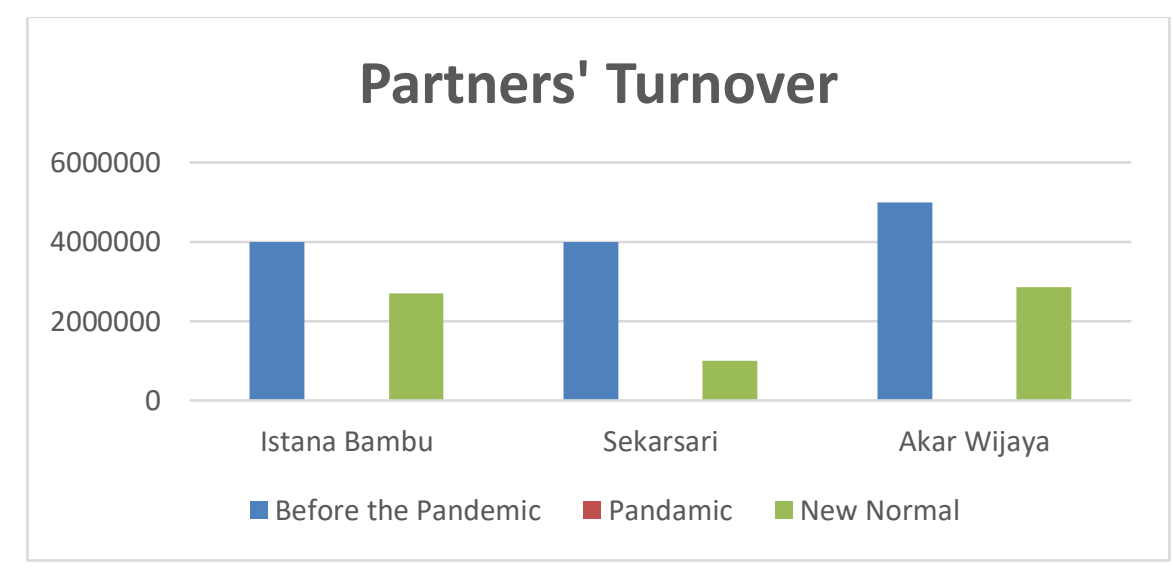

Figure 2. The improvement of Partners' Turnover

${ }^{14}$ Everett M. Rogers, Rabel J. Burdge, and Peter F. Korsching, Diffusion of Innovations (3rd Editions) (New York: The Free Press A Division of Mc Millan Publishing Co. Inc, 1983). 
Three partners experienced a drastic decrease in turnover, even at the beginning of the pandemic, one month experienced sales of 0 , this happened to only one partner but all three partners experienced the same condition, the next position was a defensive position to walk, an increase in turnover was approximately $30 \%$ compared to the time of the pandemic, but still very small compared to before the pandemic, the defensive position is quite long, partners coordinate with the PPPUD team to find alternative solutions as strategies that can be implemented to return to their original positions.

Increase product variation by up to $30 \%$, craft products from collaboration to increase product value. The benefits obtained include expanding marketing to the online market, creating new strategies to get new markets by establishing a "blue ocean" strategy, partners make various modifications from existing existing products, to develop new markets, so that they can market their products on the online platform, Bukalapak, shopee, tokopedia and Lazada, the product results are a form of collaboration from each craftsman to conceptualize products to be more valuable and have better competitiveness, each partner produces approximately 3 different product items from the 10 product items they have when This modification is on the shape and size so that it has a different function than the previous product. The following are some examples of products that are produced as follows:

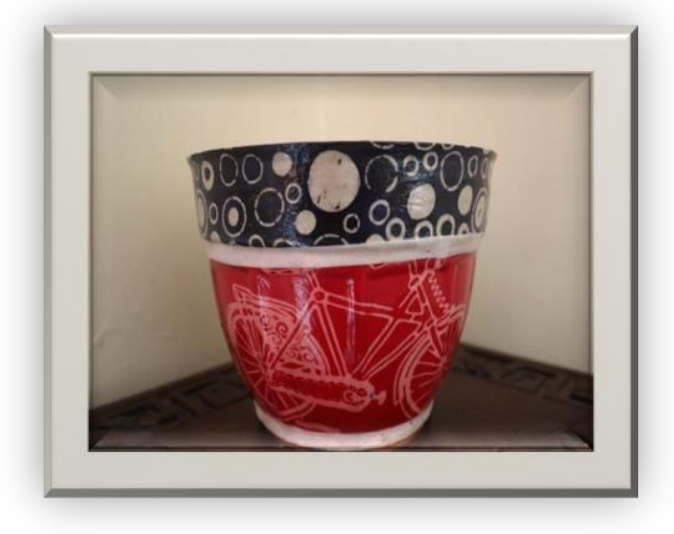

Batik pots, the work of Sekarsari's partners, combining Batik products with

Figure 3. Batik Flower Pot 


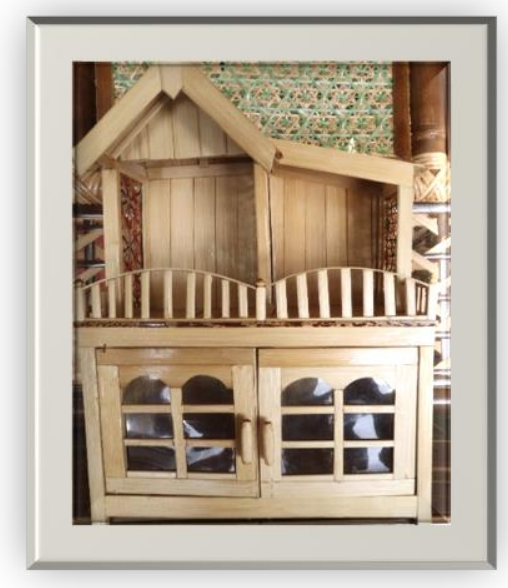

Medicine or Cosmetic Store, miniature gazebo

Figure 4. Medicine or Cosmetics Store

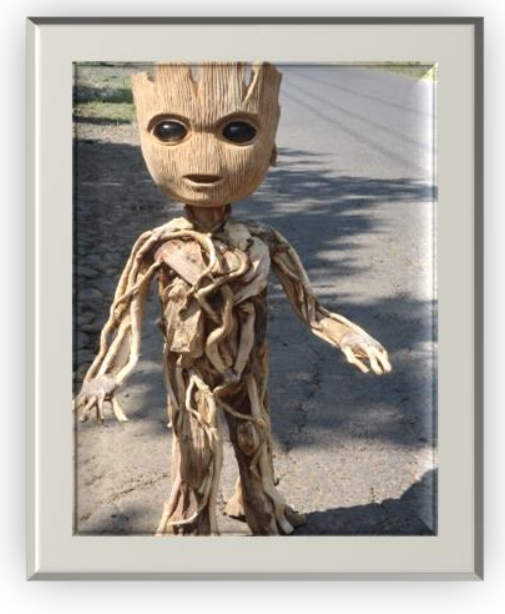

Mini Groot Statue, using local raw materials, size is reduced

Figure 5. Mini Groot Statue

The addition of partner production equipment that supports increased product quality and value. Equipment is very important to support the production process, the benefits of this activity include the addition of production equipment ranging from cutting tools, electric drills, carving tools, sandpaper machines, irat machines, cold waxing printing tables, and several other pieces of equipment that supports improving product quality and value.

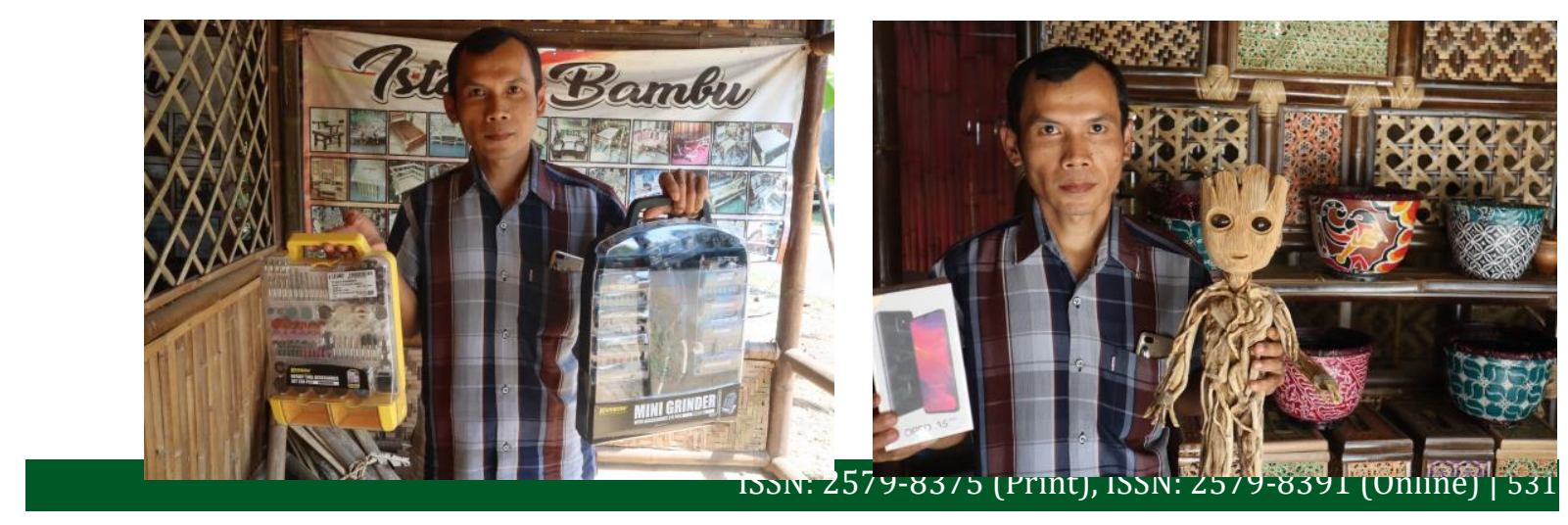


Having access to savings and loans to support the online marketing process, namely having access to BNI mobile banking and loans at BPR and BRI banks, thereby increasing partner capital by $10 \%$. Access to financial institutions is very supportive of partner business development. Financial institution loans are intended for business development starting from purchasing equipment, purchasing raw materials and other needs related to adding assets, identifying very important collateral assets, some partners own land and building assets. and vehicles, and some production equipment, not all assets owned can be guaranteed depending on who the credit application is submitted to, partners must be careful in making decisions, related to when the loan provides benefits in business development.

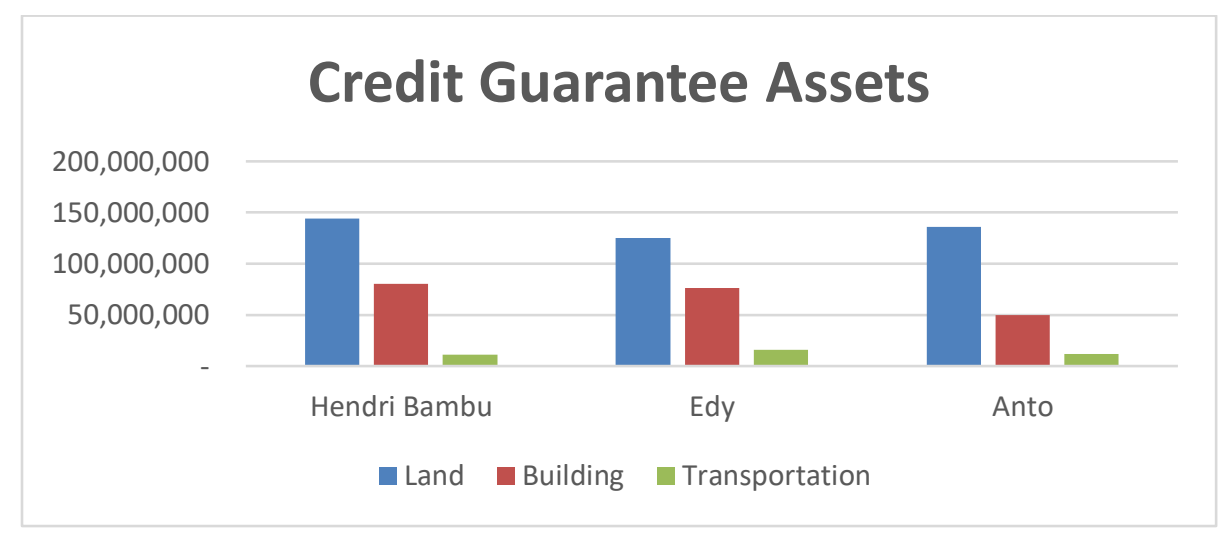

Figure 8. Identification of Financial Institution Credit Guarantee assets

Increasing knowledge of bookkeeping in Sekarsari partners, Istana Bambu and Akar Wijaya. Gradual change, separating personal expenses and business expenses so that no confusion can be detrimental to business management, the benefits obtained include partners increasing knowledge of asset, debt and capital management, in the simplest concept using manual bookkeeping, and digital using the smartphone application. Production process efficiency by $25 \%$, in handling raw materials and labour costs. The benefits of efficient handling of raw materials and labour costs are increased capacity, production of products with small variations and large quantities can reduce the cost of procuring raw materials and labour costs, in addition to selecting suppliers of raw materials, suppliers who have quality products. partners, Sekarsari, Istana Bambu, and Akar Wijaya take into account the level of production efficiency by planning raw materials and labour, as initial estimates before the production process starts.

The addition of new members of Sekarsari partners, Istana Bambu and Akar 
Wijaya, partners establish cooperation and collaboration to increase the value of the product by 60 people for all groups consisting of woven bamboo groups, household utensils groups, wall decoration groups, kitchen equipment groups, groups wood carvings, household equipment group, batik material souvenirs group, office supplies group, bamboo decoration group, wood material decoration group, wood decoration group, mini groot group, and cosmetic equipment group. Each group consisting of Batik craftsmen, bamboo craftsmen and wood craftsmen routinely communicate on the WhatsApp group in the hope of motivating them to develop their products as a result of the creativity of each cluster, to improve product quality to make it more valuable.

Innovative product variations in Batik, sculpture and roots to penetrate the online market with shapes and variations required by the market, with the most efficient delivery concept, with product variations increasing by $70 \%$. To fulfil the online market, activities are focused on how to add innovative products to sculpture, Akar Wijaya and Istana Bambu by developing products based on the results of collaboration and development from each partner, one of the innovative products produced can be presented as follows:

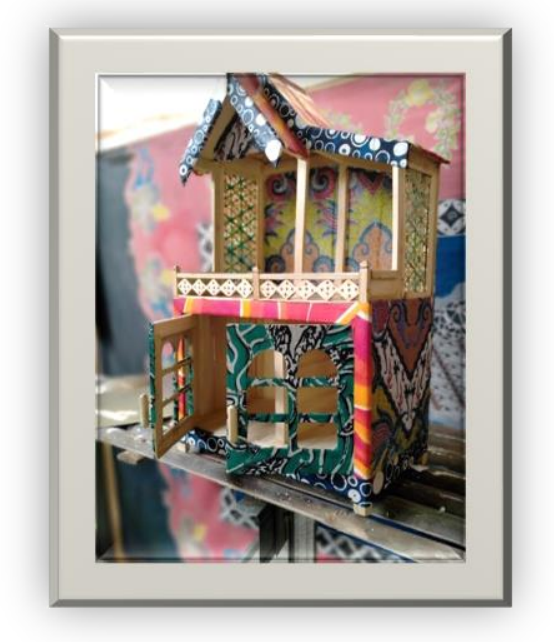

Medicine or Cosmetics Store, and a miniature gazebo in collaboration

Figure 9. Products of Collaboration

Increasing knowledge of manual financial statement administration bookkeeping. Partners are provided with manual administration, as initial guidelines for carrying out online bookkeeping, cash disbursement transaction books, cash receipt transaction books, general journals, and balance sheets and income statements, the benefit is that partners can find out how much business capital they have or assets they have. To get profit in business, besides partners also know how many assets they have for business management.

Preparing and improving the digital administrative bookkeeping. The benefits of this activity include the addition of smartphone devices in addition to developing a marketing process on a digital platform, such as Bukalapak, Shopee, Tokopedia and 
Lazada. This telephone device can function as a tool to digitally recap transaction data using the E-Accounting EMKM application, journals, or other applications, which provides online bookkeeping services, selected the simplest one and according to the needs of each partner.

The Addition of 10 Standard Operational Production Process Procedures including wall decoration products, cold waxing printing Batik, combination Batik, medicine cabinet, bamboo wall decoration, tissue holder, groot statues, room sketches, bird statue and decorative lamps. This activity provides benefits to production planning that takes into account standard operating procedures for initial planning, budget planning so that the minimum possible expenditure can be identified for waste, this procedure is also used as a quality standard, so that when the product is done by different people, the quality of the product can be identified. awake and consumers are not harmed because the product does not match expectations. 
Partners' Contribution to Implementation

The benefit in implementing PPPUD Faculty of Economics and Business, University of Peradaban activities is that partners consider increasing efficiency and productivity as the focus of PPPUD service activities in 2020, the contribution of partners in carrying out activities including enthusiasm in participating in all scheduled and unscheduled activities, participating in training activities based on Health protocols, obeying training implementation regulations, cooperative to be invited to Collaborate and provide a place, communication with local governments, communication with village governments, providing supporting equipment, and support for various programs in collaboration with the University of Peradaban and the Office of Cooperatives and UMKM Purbalingga Regency.

Partners of the Purbalingga Regency Cooperative and UMKM Service, are committed to providing a new place to accommodate all the products of batik, bamboo and sculpture, apart from tourist areas as well as modern shops such as supermarkets, and outlets that are provided free of charge to MSMEs of Purbalingga Regency. The Purbalingga government is also committed to assisting in branding, mentoring marketing, access to loans and exhibitions regularly to introduce "Tuka-Tuku" as a concern for quality local products so that the turnover of Purbalingga MSMEs is increasing.

\section{Discussion}

Some of the obstacles faced during the implementation of PPPUD activities in Purbalingga Regency include the Covid-19 pandemic that occurred in Indonesia, including in Purbalingga Regency, these constraints affect the implementation of the activity schedule, which requires us to make changes to the schedule after getting recommendations from the District Cooperatives and UMKM Office Purbalingga, the next obstacle is the limited time for the implementation of training, according to the Health protocol, the duration of the training cannot be fully carried out with a long duration, but the number of hours is limited so that the implementation of training is often accelerated and the schedule is postponed after getting a recommendation from the Office.

The next obstacle is the turnover of PPPUD activity partners, which was at zero percent, there was no sales turnover at all at the start of the pandemic, first, even though as a product that has advantages in Purbalingga, when juxtaposed with products of basic needs, therefore this product will definitely shifted compared to other products that are categorized as primary needs, various studies state that one of the strategies that can be taken is implementing a digital marketing strategy, this strategy can be carried out during a pandemic ${ }^{15}$, Purbalingga SMEs continues to strive to continue promotion to get product

${ }^{15}$ Putri Lestari and Muchammad Saifuddin, "Implementasi Strategi Promosi Produk Dalam Proses Keputusan Pembelian Melalui Digital Marketing Saat Pandemi Covid'19," Manova (Jurnal Manajemen dan Inovasi) 2, no. 2 (2020): 23-31. 
orders at the size and function different through online marketing.

The increasing number of product marketing using online platforms starting from Bukalapak, Tokopedia, shopee and Lazada, so that partners have the urge to produce products that are more functional for primary needs, so it is very important to pay attention to designs and products that the online market needs ${ }^{16}$, the easier and more trusting consumers online platforms, encouraging SMEs to market them on online platforms, The next support is from the Purbalingga Regency Cooperative and UMKM Office, the PPPUD program synergizes with the Service program in recovery to New Normal conditions at MSMEs, besides that the training program received a positive response from the Purbalingga Regency Cooperative and UMKM Office and trained mentoring partners, because it was considered an activity positive that can improve product quality and creativity.

Based on the existing constraints, the solutions offered include compiling a postpandemic schedule that starts to subside a little to the new normal status, waiting for recommendations from the Purbalingga Regency Cooperative and UMKM Office and seeing the Health protocol guidelines in organizing activities in PPPUD training and counseling, besides that it is also based on the program. PPPUD in increasing product variety is focused on the needs of online buyers. Online platforms such as Bukalapak, Shopee, Tokopedia and Lazada often require functional products in relatively small product sizes and support home work or basic necessities ${ }^{17}$.

The team provides assistance both in FGD discussions and in interactive discussions on WhatsApp regularly in increasing product innovation, besides that the PPPUD team also provides training on product manufacturing, especially for batik, bamboo and wood craftsmen partners. It is hoped that this can become an activity or collaboration in the form of collaboration products, namely each individual provides use of their skills to improve product quality so that products have high competitiveness and increase product value ${ }^{18}$.

\section{Conclusion}

The success of implementing activities includes an increase in turnover for

${ }^{16}$ Inggri Septianie and Mariati Tirta Wiyata, "Pengaruh Kemudahan Dan Kepercayaan Terhadap Niat Pembelian Secara Online Pada Platform E-Commerce Lazada Indonesia," Winter Journal: IMWI Student Research Journal 1, no. 1 (2020): 73-83; Ariesa Pandanwangi et al., "Pendampingan Komunitas Pembatik Melalui Pelatihan Alih Pengetahuan Membatik Dengan Material Berbasis Kearifan Lokal."

${ }^{17}$ Taufik Taufik and Eka Avianti Ayuningtyas, "Dampak Pandemi Covid 19 Terhadap Bisnis Dan Eksistensi Platform Online," Jurnal Pengembangan Wiraswasta 22, no. 01 (2020): 21-32, http://ejurnal.stieipwija.ac.id/index.php/jpw ; Muh Barid Nizarudin Wajdi et al., "Pendampingan Redesign Pembelajaran Masa Pandemi Covid-19 Bagi Tenaga Pendidik Di Lembaga Pendidikan Berbasis Pesantren Di Jawa Timur," Engagement: Jurnal Pengabdian Kepada Masyarakat 4, no. 1 (2020): 266-277, http://engagement.fkdp.or.id/index.php/engagement/article/view/193.

18 Inten Pertiwi, "Inovasi Desain Produk Dan Kemasan Melalui Kolaborasi Kreatif Brand Kosmetik Dengan Produsen Makanan," in SENADA (Seminar Nasional Desain Dan Arsitektur), vol. 3, 2020, 303-309, https://eprosiding.idbbali.ac.id/index.php/senada/article/view/342. 
partners, so that their income increases, this success is an effort of the mission of innovation process that encourages individuals to adopt online marketing, and the ease and trust of SMEs in existing platforms, other successes include increased product capacity. There are more product variations, wider marketing networks, additional support businesses, increased access to financial institutions, and increased production cost efficiency.

There is a contribution from partners to work well together, to carry out PPPUD teamwork programs, group members are very enthusiastic about following the various schedules that are implemented, there is a transfer of knowledge from partners who are already proficient to prospective new partner members to continue to be excited about developing products, in addition to these various relative strategies have been running effectively to return to normal conditions, where the initial stages have been better, namely the post-COVID-19 pandemic orders have begun to subside, then the Service's support in implementing the program, as a form of sustainable cooperation in assisting MSMEs in Purbalingga Regency, will develop for other cooperation with large industries, supermarkets, malls and hotels, to carry out various breakthroughs to improve the marketing performance of Purbalingga handicraft products.

\section{Acknowledgements}

The joy of the Purbalingga district's superior product development program is carried out in the Covid-19 pandemic conditions, program implementation may be better than not during the pandemic, but program implementation can overcome all obstacles and obstacles, and can be in line with the Purbalingga Regency Cooperative and MSME Office in restoring performance UMKM, the author expresses many thanks to the Ministry of Research and Technology of National Agency for Research and Technology for funding this grant program and thanks to the Purbalingga Regency Cooperatives and UMKM Office for their cooperation and support in the smooth implementation of the program. This program is also in line with the Dinporapar, Dindikbud, Pemdes, BKK in developing and synergizing tourism potential nature, craft, Batik, culinary, cultural arts and the potential of its youth.

\section{References}

Amalia, Devi Rizki, Sri Nuringwahyu, and Ratna Nikin Hardati. "Analisis Lingkungan Dalam Menentukan Strategi Yang Tepat (Studi Pada Kerajinan Kayu Tohu Srijaya Kota Batu)." Jiagabi (Jurnal Ilmu Administrasi Niaga / Bisnis) 7, no. 3 (2018): 109116.

Anis, Tuwaidan. "PKM Kelompok Pengrajin Sofa Di Desa Watutumou Kecamatan Kalawat Kabupaten Minahasa Utara Provinsi Sulawesi Utara.” Lex Et Societatis 6, no. 8 (2019): 31-37. 
Ariesa Pandanwangi, Ida, Olga Catherina Pattipawaej, and Erwani Merry Sartika. "Pendampingan Komunitas Pembatik Melalui Pelatihan Alih Pengetahuan Membatik Dengan Material Berbasis Kearifan Lokal." Engagement: Jurnal Pengabdian Kepada Masyarakat 3, no. 1 (2019): 68-79. http://engagement.fkdp.or.id/index.php/engagement/article/view/51.

Arifin, Alvin. "Manajemen Sumber Daya Manusia Pada Masyarakat Desa." Bunga Rampai Gubahan Akademisi Manajemen 2019 (2019): 1.

Arka Sudarsana, Komang Ary Niatika. "Analisis Skala Ekonomis Industri Kerajinan Patung Kayu Di Kecamatan Ubud Kabupaten Gianyar.” E-Jurnal Ekonomi Pembangunan Universitas Udayana 9, no. 10 (October 18, 2019): 195-2500. https://ojs.unud.ac.id/index.php/eep/article/view/46197.

Bismala, Lila. "Analisis Strategi Pemasaran Pada UMKM Di Sumatera Utara Untuk Meningkatkan Daya Saing UMKM." Jurnal Pembangunan Perkotaan 2, no. 2 (2014): 126-134.

Harinie, Luluk Tri, and Alexandra Hukom. "Pendampingan Dalam Memasarkan Produk Hasil Usaha UKM Melalui Penggunaan Media Sosial Di Kabupaten Gunung Mas Kalimantan Tengah." Engagement: Jurnal Pengabdian Kepada Masyarakat 4, no. 1 (2020): 51-59. http://engagement.fkdp.or.id/index.php/engagement/article/view/179.

Ikqbal, Muhamad. "Pengaruh Desain Produk Dan Kualitas Produk Terhadap Keunggulan Bersaing (Survey Pada Pengrajin Batik Di Kota Tasikmalaya)." Universitas Siliwangi, 2020.

Kurniawan, Kurniawan, Dede Nurdiawati, Rianto Rianto, and Varahdilah Varahdilah. "Peningkatan Skill Teknologi Pengrajin Produk Unggulan Kabupaten Purbalingga Pada Kerajinan Batik, Kerajinan Bambu Dan Seni Patung." Jurnal Abdimas PHB: Jurnal Pengabdian Masyarakat Progresif Humanis Brainstorming 3, no. 1 (2020): 32-46.

Lestari, Putri, and Muchammad Saifuddin. "Implementasi Strategi Promosi Produk Dalam Proses Keputusan Pembelian Melalui Digital Marketing Saat Pandemi Covid'19." Manova (Jurnal Manajemen dan Inovasi) 2, no. 2 (2020): 23-31.

Pakpahan, Aknolt Kristian. “Covid-19 Dan Implikasi Bagi Usaha Mikro, Kecil, Dan Menengah." Jurnal Ilmiah Hubungan Internasional (2020): 59-64.

Permana, Rahayu. “Topi Bambu Tangerang (Kearifan Lokal Berbasis Ekonomi Kreatif).” Tsaqofah 17, no. 2 (2019): 137-148.

Pertiwi, Inten. "Inovasi Desain Produk Dan Kemasan Melalui Kolaborasi Kreatif Brand Kosmetik Dengan Produsen Makanan." In SENADA (Seminar Nasional Desain Dan Arsitektur), 3:303-309, 2020. https://eprosiding.idbbali.ac.id/index.php/senada/article/view/342. 
Prameswari, Nadia Sigi, Pratama Bayu Widagdo, and Eko Sugiarto. "Perluasan Jaringan Pemasaran Melalui Kemitraan Dengan Marketplace Bagi PKL Dampak Relokasi Pemkot Surakarta." Citradirga-Jurnal Desain Komunikasi Visual dan Intermedia 1, no. 2 (2019): 1-8.

Putra, Rangga Sa'adillah Sandhy Atma. "Pembelajaran Pendidikan Agama Islam Melalui Pendekatan Saintifik Dalam Membentuk Sikap Spiritual Siswa Sekolah Menengah Atas Di Sidoarjo (Studi Fenomenologi Pengalaman Guru Dan Siswa Pada SMA Di Sidoarjo)." Universitas Muhammadiyah Malang, 2020. http://eprints.umm.ac.id/65683/.

Ridwan, Muhammad, and Massad Hatuwe. "Pembinaan Industri Kecil Dan Menengah Pada Dinas Perindustrian, Perdagangan, Koperasi Dan UMKM Kota Bontang." Jurnal Administrative Reform (JAR) 2, no. 2 (2017): 187-199.

Rogers, Everett M., Rabel J. Burdge, and Peter F. Korsching. Diffusion of Innovations (3rd Editions). New York: The Free Press A Division of Mc Millan Publishing Co. Inc, 1983.

Rozaki, Abdur, and Siti Rohaya. "Memberdayakan Desa Melalui Pariwisata Berbasis BUMDES." Engagement: Jurnal Pengabdian Kepada Masyarakat 3, no. 1 (2019): 120. http://engagement.fkdp.or.id/index.php/engagement/article/view/46.

Septianie, Inggri, and Mariati Tirta Wiyata. "Pengaruh Kemudahan Dan Kepercayaan Terhadap Niat Pembelian Secara Online Pada Platform E-Commerce Lazada Indonesia." Winter Journal: IMWI Student Research Journal 1, no. 1 (2020): 73-83.

Taufik, Taufik, and Eka Avianti Ayuningtyas. "Dampak Pandemi Covid 19 Terhadap Bisnis Dan Eksistensi Platform Online." Jurnal Pengembangan Wiraswasta 22, no. 01 (2020): 21-32. http://ejurnal.stieipwija.ac.id/index.php/jpw .

Wajdi, Muh Barid Nizarudin, M Burhanuddin Ubaidillah, Sri Mulyani, Khoirul Anwar, Lailatul Istiqomah, Fauziyah Rahmawati, Sholihatul Atik Hikmawati, Diah Retno Ningsih, and Hasan Syaiful Rizal. "Pendampingan Redesign Pembelajaran Masa Pandemi Covid-19 Bagi Tenaga Pendidik Di Lembaga Pendidikan Berbasis Pesantren Di Jawa Timur." Engagement: Jurnal Pengabdian Kepada Masyarakat 4, no. 12020$):$ 266-277. http://engagement.fkdp.or.id/index.php/engagement/article/view/193.

Wulandari, Siti Zulaikha, Suwaryo Suwaryo, and Suci Indriati. "Peningkatan Kapasitas Usaha Batik Cap Motif Khas Pesona Gua Lawa Bagi Kelompok Batik Sekarsari Purbalingga." In Prosiding. Vol. 7, 2017. 